\title{
Ryegrasses with increased water soluble carbohydrate: evaluating the potential for grazing dairy cows in New Zealand
}

\author{
G.P. COSGROVE 1 , J.L. BURKE ${ }^{2}$, A.F. DEATH ${ }^{1}$, M.J. HICKEY ${ }^{1}$, D. PACHECO ${ }^{1}$ and G.A. LANE ${ }^{1}$ \\ AgResearch Grasslands, PB 11008, Palmerston North \\ Massey University, PB 11222, Palmerston North \\ gerald.cosgrove@agresearch.co.nz
}

\begin{abstract}
An elevated concentration of water soluble carbohydrate (WSC) in grasses may increase the availability of readily degradable energy, increase milk production and improve the efficiency of nitrogen utilisation. Two ryegrasses with elevated WSC, a tetraploid Italian (IRG) and a diploid perennial selected for higher WSC (HSG), were compared against a standard diploid perennial (STG) during spring 2004 and 2005, and autumn 2006 and 2007. Groups of cows $(n=20)$ grazed each grass type for periods of 6 weeks in spring and 2 weeks in autumn. During spring, the 'high' WSC grasses were $20-40 \mathrm{~g} / \mathrm{kg}$ DM higher in concentration of WSC than the standard $(\mathrm{P}<0.01)$, whereas in autumn the difference was smaller and not significant. The production of milk and milksolids (MS) did not differ significantly among grasses in spring or in autumn 2006. In autumn 2007, MS production was higher for HSG than STG (1.09 and $0.99 \mathrm{~kg} \mathrm{MS} / \mathrm{cow} /$ day for $\mathrm{HSG}$ and $\mathrm{STG}$, respectively, $\mathrm{P}=0.006)$. While the greater $\mathrm{MS}$ production cannot be attributed to higher WSC per se, it may be related to other differences between grass types, such as a lower fibre content of the high WSC grasses, or factors affecting intake and the partitioning of nutrients to production or body reserves by cows during late lactation.
\end{abstract}

Keywords: perennial ryegrass, annual ryegrass, water soluble carbohydrate, milk production, milksolids production

\section{Introduction}

Energy intake is usually the limiting factor for milk production from grass-fed cows, whereas protein intake is usually surplus to requirements. The low content of readily fermentable energy (primarily water soluble carbohydrate; WSC) in ryegrass often limits energy availability in the rumen and, consequently, the microbial capture of degrading grass protein. When the supply of WSC is inadequate or not available in synchrony with the rapidly degradable plant protein, the excess protein is degraded to ammonia and excreted (Nocek \& Russell 1988; Kingston-Smith \& Theodorou 2000). There are several ways additional energy might be supplied. Supplementation of grass-fed cows with additional WSC increased milk and milk protein yield when the grass contained $18 \%$ crude protein $(\mathrm{CP})$ but not when the concentration was $13 \%$ CP (Carruthers \& Neil 1997). However, energy-dense supplements are expensive in NZ, and grasses with increased WSC might be a more effective option for pasture-based dairy production.

Previous studies, in the UK and The Netherlands, have examined the effects of ryegrasses with higher WSC on milk production and nitrogen $(\mathrm{N})$ utilisation. The results are equivocal. The UK studies compared a grass selected for high WSC (a 'high sugar' ryegrass; HSG) against a standard control grass at three stages of lactation (early, mid and late). In late-lactation (conducted mid-summer), there was a significant $21 \%$ increase in milk production attributable to the $39 \mathrm{~g} / \mathrm{kg}$ DM higher concentration of WSC (Miller et al. 2001b). However, there were no effects on milk production in mid-lactation when the difference in WSC concentrations was 40-70 g/kg DM (Miller et al. 2000, 2001a), or in early-lactation when the difference was 82 $\mathrm{g} / \mathrm{kg}$ DM (Moorby et al. 2006). While the milk yield response differed among these studies, a more consistent effect across studies was the improved retention of N (Miller et al. 2001; Moorby et al. 2006). In studies in the Netherlands, neither milk production nor $\mathrm{N}$ retention was improved by increases in WSC of 24-32 g/kg DM (Tas et al. 2005, 2006; Taweel et al. 2005, 2006). Orr et al. (2001) manipulated the timing of pasture allocation during the day to maximise the use of afternoon grass which has a naturally higher concentration of WSC. In that study, cows given their daily allowance of grass following the afternoon milking (204 g WSC/kg DM and 20\% DM) produced $5 \%$ more milk than cows given a similar daily amount allocated following the morning milking (175 g WSC/ $\mathrm{kg} \mathrm{DM}$ and $18 \% \mathrm{DM}$ ) even though total dry matter intake was similar. A production response to higher WSC has also been recorded in sheep (Lee et al. 2001; see Edwards et al. 2007 for a comprehensive review of effects of WSC on other responses such as rumen function).

The objective of this study was to determine the effect of increased concentrations of WSC in ryegrass on milk and milksolids production from cows grazing grassonly pastures. The high WSC ryegrasses included a 
Table 1 Descriptive summary of experiments conducted during spring 2004 and 2005 and autumn 2006 and 2007.

\begin{tabular}{|c|c|c|c|c|c|}
\hline Season & Year & Period & $\begin{array}{l}\text { Duration } \\
\text { (days) }\end{array}$ & Design & $\begin{array}{c}\text { Experimental } \\
\text { unit }\end{array}$ \\
\hline \multirow[t]{2}{*}{ Spring } & 2004 & $\begin{array}{l}\text { October- } \\
\text { November }\end{array}$ & 42 & $\begin{array}{c}\text { Cross-over; } 6 \text { groups } \\
\text { x } 3 \text { periods }\end{array}$ & group \\
\hline & 2005 & $\begin{array}{l}\text { September- } \\
\text { October }\end{array}$ & 42 & $\begin{array}{c}\text { Cross-over; } 6 \text { groups } \\
\text { x } 3 \text { periods }\end{array}$ & group \\
\hline \multirow[t]{2}{*}{ Autumn } & 2006 & May & 14 & Continuous ${ }^{1}$ & cow \\
\hline & 2007 & May & 17 & $\begin{array}{c}\text { Cross-over; } 2 \text { groups } \\
\text { x } 2 \text { periods }\end{array}$ & group \\
\hline
\end{tabular}

${ }^{1}$ completely randomised; no cross-over aspect in the design

Table 2 Mean $( \pm \mathrm{SD})$ parity (number of lactations), liveweight $(\mathrm{kg})$, condition score (1-10 scale) and days in milk of cows at the start of each experimental period during spring and autumn.

\begin{tabular}{llcccc}
\hline Season & Year & Parity & Liveweight & $\begin{array}{c}\text { Condition } \\
\text { score }\end{array}$ & $\begin{array}{c}\text { Days in } \\
\text { milk }\end{array}$ \\
\hline \multirow{2}{*}{ Spring } & 2004 & $4.1 \pm 1.0$ & $489 \pm 39$ & $4.4 \pm 0.3$ & $68 \pm 3.9$ \\
& 2005 & $4.4 \pm 1.0$ & $511 \pm 41$ & $4.1 \pm 0.2$ & $43 \pm 6.7$ \\
\multirow{3}{*}{ Autumn } & 2006 & $4.4 \pm 1.0$ & $519 \pm 39$ & $3.9 \pm 0.3$ & $225 \pm 12.0$ \\
& 2007 & $4.8 \pm 0.9$ & $540 \pm 37$ & $4.1 \pm 0.3$ & $220 \pm 17.3$ \\
\hline
\end{tabular}

tetraploid annual with inherently higher concentrations of WSC, and a diploid perennial selected for higher concentrations of WSC, and both were compared against a standard diploid perennial. Components of this study relating to the effects of higher WSC on rumen and milk metabolites (Tavendale et al. 2006) and nitrogen partitioning (Cosgrove et al. 2007) have been reported recently.

\section{Materials and Methods}

This study was conducted at Massey University No 4 Dairy Farm, located on Tokomaru silt loam soils, near Palmerston North. Measurements were made in spring 2004 and 2005, and autumn 2006 and 2007 (see Table 1 for details of experiments).

\section{Treatments and experimental design}

The study compared three, endophyte-free ryegrass 'types': a standard NZ diploid perennial ryegrass (Lolium perenne, cv. Impact; STG), a UK 'high sugar' diploid perennial ryegrass (cv. AberDart; HSG) and a $\mathrm{NZ}$ tetraploid Italian ryegrass (Lolium multiflorum, cv. Moata; IRG). This treatment design allowed for the effects of higher WSC to be evaluated by comparisons between 1) perennials and 2) annual and perennial. A balanced cross-over design was used for measurements over 6 weeks in spring 2004 and 2005 (see Table 1). Two sub-groups of cows each crossed over to each of the other treatments after 2 weeks and 4 weeks of measurements, using a pre-determined allocation sequence. The purpose of the cross-over groups was to provide an estimate of experimental error. For autumn 2006, the measurement period was 2 weeks. A crossover design was not possible, and statistical comparisons were based on using the cow as the experimental unit. For autumn 2007, a cross-over design was again used with 10 days for the first period of the cross-over and 7 days for the second period. For this season, no Italian ryegrass was available because of poor establishment, and the design was based on two treatments (standard and high WSC perennials) with each group of cows crossing over to the alternate treatment after 10 days.

\section{Animals}

For each measurement period, 60 Friesian cows were selected from the main herd and allocated to three treatment groups of 20 cows each, balanced for age, production worth, days-in-milk and current production based on the most recent available herd-test data. In autumn 2007, the 60 cows were allocated to two groups of 30 cows. Table 2 summarises cow descriptors for each experiment.

\section{Pastures}

In autumn 2004, seven paddocks (approximately 2 ha each) were sown with the STG and HSG perennial ryegrasses at $16 \mathrm{~kg}$ seed/ha following full cultivation. One randomly-selected half of each paddock was sown with the STG and the other half sown with the HSG. Of 
these seven paddocks, five had previously been in turnips for late-summer feed, one in Italian ryegrass and one in perennial ryegrass. A further three paddocks (ex turnips) were sown with the Italian ryegrass at $30 \mathrm{~kg}$ seed/ha. Each of the grasses was sown without white clover.

\section{Pasture allocation}

During measurement periods, groups of cows were offered fresh breaks of grass at 8:00 AM and at 4:00 PM, immediately following milking. The target for pregrazing and post-grazing pasture mass was $2600 \mathrm{~kg}$ $\mathrm{DM} / \mathrm{ha}$ and $1600 \mathrm{~kg} \mathrm{DM} / \mathrm{ha}$, respectively. For each treatment group the area offered each day was calculated from the difference between pre-grazing mass (determined using an electronic rising plate meter, Farmworks Precision Farming Systems, Feilding) and the target residual pasture mass, allowing for intakes of $18 \mathrm{~kg} \mathrm{DM} / \mathrm{cow} /$ day. Of the total area for grazing each day, $40 \%$ was offered following the morning milking and $60 \%$ following the afternoon milking. This ratio matched the distribution of grazing time (and hence approximate distribution of DM intake) of cows offered fresh pasture twice daily, determined in other work (Rook \& Huckle 1995; Cosgrove et al. 2006).

\section{Measurements}

Milk yield (kg/cow) was recorded at each milking using an automated system (Alpro, De-Laval). Milk samples were collected twice weekly from proportional in-line samplers at a PM and the following AM milking. These samples were analysed for fat and protein (FT 6000 Fourier Transform infrared analyser, Foss Electric, Hillerød, Denmark). Daily milksolids production, the sum of fat and protein yield, was calculated using the fat and protein concentrations and the milk yields measured on the days of sample collection.

Samples of pasture offered to cows were taken from the allocated break at 8:00 AM and at 4:00 PM, 2-3 times per week. These samples were hand-plucked to represent herbage being consumed by the cows in each treatment. Samples were immediately frozen in liquid nitrogen in the field, stored frozen, and subsequently freeze-dried and ground using a 1-mm sieve size. They were then analysed using near-infrared reflectance spectroscopy (FeedTech, AgResearch Grasslands, Palmerston North) to estimate water soluble carbohydrate, protein, neutral detergent- and acid detergent fibre, organic matter digestibility and metabolisable energy. Dry matter percent was determined from the sample fresh weight, and the weight following freeze-drying. Separate samples were taken in the morning (AM) and afternoon (PM) to account for the diurnal changes in chemical composition, especially WSC. The data presented are the simple means of constituents measured in AM and PM samples.

\section{Statistical analysis}

With the exception of autumn 2006, a balanced crossover design was used in which groups of cows were allocated to grasses for defined periods (three consecutive periods of 2 weeks in spring; 10 days and 7 days for the first and second period, respectively, in autumn 2007) in a pre-determined sequence such that each group grazed each treatment. Periods provided temporal replication. In autumn 2006, each group of cows was allocated to a single treatment for the 2 week measurement duration. Treatment means were compared by analysis of variance within season and year.

\section{Results \\ Pasture composition}

The concentrations of the main chemical constituents of the grasses offered to cows during each season are shown in Table 3. The HSG and IRG grasses contained higher concentrations of WSC than the standard perennial during spring $2004(\mathrm{P}=0.003)$ and $2005(\mathrm{P}=0.012)$. In autumn, the difference among grasses was not significant $(\mathrm{P}=0.08$ and 0.07 for 2006 and 2007, respectively). Higher concentrations of WSC in the IRG and the HSG in spring were offset mainly by lower concentrations of protein (as in spring 2004) or structural fibre (spring 2005), compared with STG.

\section{Yields of milk and milksolids}

In spring, there were no significant differences among grasses in the yield of milk or milksolids, although in spring 2005 milksolids tended to be higher $(\mathrm{P}=0.06)$ from cows grazing Italian ryegrass $(2.14 \mathrm{~kg} \mathrm{MS} / \mathrm{cow} /$ day) compared with those grazing the standard perennial (2.03 kg MS/cow/day; Table 4). In autumn 2006, the milk yield for cows grazing the Italian ryegrass $(12.0 \mathrm{~kg}$ milk/cow/day) and the HSG (11.3 kg/cow/day) also tended to be higher $(\mathrm{P}=0.08)$ than for those grazing the standard (9.6 kg/cow/day); and in autumn 2007 milk yields were higher $(\mathrm{P}=0.05)$ for the HSG $(11.7 \mathrm{~kg} / \mathrm{cow} /$ day) compared with the standard $(11.0 \mathrm{~kg} / \mathrm{cow} /$ day $)$. Milksolids yield did not differ significantly among treatments in autumn 2006 ( $\mathrm{P}=0.15)$, but in autumn 2007 was higher ( $\mathrm{P}=0.006)$ for HSG (1.09 kg/cow/day) than for the standard $(0.99 \mathrm{~kg} / \mathrm{cow} /$ day $)$. The fat and protein concentrations of milk were not significantly influenced by grass type in spring or autumn (data not presented), and the milksolids response in autumn reflects the higher milk yield.

\section{Discussion}

The objective of this study was to examine the responses of cows to grazing grasses with elevated levels of WSC. Two examples of such grasses were selected; a tetraploid Italian ryegrass that inherently has higher levels of 
Table 3 The concentrations (g/kg DM) of water soluble carbohydrate (WSC), crude protein, neutral and acid detergent fibre (NDF, ADF), organic matter digestibility (OMD), metabolisable energy density (ME; MJ/ $\mathrm{kg} \mathrm{DM}$ ) and dry matter (DM; g/kg DM) of the standard perennial ryegrass (STG), a 'high WSC' perennial ryegrass (HSG) and tetraploid Italian ryegrass (IRG) during experimental periods in spring and autumn (mean of samples taken at 8:00 AM and 4:00 PM).

\begin{tabular}{|c|c|c|c|c|c|c|c|c|c|c|}
\hline Season & Year & & Treatment & WSC & Protein & NDF & ADF & OMD & ME & DM \\
\hline \multirow[t]{10}{*}{ Spring } & 2004 & & STG & 167 & 227 & 489 & 235 & 827 & 12.4 & 203 \\
\hline & & & HSG & 200 & 196 & 475 & 235 & 822 & 12.4 & 220 \\
\hline & & & IRG & 208 & 203 & 472 & 232 & 853 & 12.7 & 185 \\
\hline & & $P$ & & 0.003 & 0.036 & 0.08 & 0.337 & 0.015 & 0.033 & 0.009 \\
\hline & & SEM & & 5.4 & 3.2 & 5.9 & 2.1 & 6.0 & 0.1 & 5.5 \\
\hline & 2005 & & STG & 195 & 235 & 393 & 212 & 882 & 12.7 & 187 \\
\hline & & & HSG & 215 & 234 & 376 & 204 & 890 & 12.9 & 191 \\
\hline & & & IRG & 215 & 255 & 360 & 200 & 927 & 13.2 & 157 \\
\hline & & $P$ & & 0.012 & 0.114 & 0.07 & 0.19 & 0.002 & 0.003 & 0.001 \\
\hline & & SEM & & 4.0 & 7.7 & 9.5 & 2.3 & 4.9 & 0.1 & 3.5 \\
\hline \multirow[t]{10}{*}{ Autumn } & 2006 & & STG & 161 & 256 & 415 & 211 & 866 & 12.6 & 160 \\
\hline & & & HSG & 170 & 262 & 390 & 205 & 880 & 12.7 & 162 \\
\hline & & & IRG & 159 & 283 & 376 & 198 & 914 & 13.0 & 136 \\
\hline & & $\mathrm{P}$ & & 0.08 & $<0.001$ & $<0.001$ & 0.012 & $<0.001$ & $<0.001$ & $<0.001$ \\
\hline & & SEM & & 4.9 & 6.2 & 7.8 & 3.7 & 6.7 & 0.1 & 4.0 \\
\hline & 2007 & & STG & 150 & 249 & 431 & 247 & 822 & 12.2 & 180 \\
\hline & & & HSG & 159 & 255 & 402 & 219 & 835 & 12.4 & 190 \\
\hline & & & IRG & NA & NA & NA & NA & NA & NA & $\mathrm{NA}^{1}$ \\
\hline & & $\mathrm{P}$ & & 0.07 & 0.5 & 0.08 & 0.25 & 0.26 & 0.17 & 0.36 \\
\hline & & SEM & & 2.5 & 4.3 & 10.5 & 4.9 & 7.6 & 0.1 & 9.1 \\
\hline
\end{tabular}

${ }^{1}$ annual ryegrass not included in study during autumn 2007

Table 4 The yields of milk and milksolids (kg/cow/day) for cows grazing the standard perennial ryegrass (STG), a 'high WSC' perennial ryegrass (HSG) or a tetraploid Italian ryegrass (IRG) during spring and autumn.

\begin{tabular}{|c|c|c|c|c|c|c|c|}
\hline Season & Year & & STG & HSG & IRG & $\mathrm{P}$ & SEM \\
\hline \multirow[t]{2}{*}{ Spring } & 2004 & $\begin{array}{l}\text { Milk } \\
\text { Milksolids }\end{array}$ & $\begin{array}{l}20.9 \\
1.72\end{array}$ & $\begin{array}{l}20.9 \\
1.70\end{array}$ & $\begin{array}{l}21.7 \\
1.76\end{array}$ & $\begin{array}{l}0.34 \\
0.31\end{array}$ & $\begin{array}{l}0.37 \\
0.02\end{array}$ \\
\hline & 2005 & $\begin{array}{l}\text { Milk } \\
\text { Milksolids }\end{array}$ & $\begin{array}{l}25.1 \\
2.03\end{array}$ & $\begin{array}{l}25.5 \\
2.09\end{array}$ & $\begin{array}{l}25.7 \\
2.14\end{array}$ & $\begin{array}{l}0.18 \\
0.06\end{array}$ & $\begin{array}{l}0.22 \\
0.02\end{array}$ \\
\hline \multirow[t]{2}{*}{ Autumn } & 2006 & $\begin{array}{l}\text { Milk } \\
\text { Milksolids }\end{array}$ & $\begin{array}{c}9.6 \\
0.89\end{array}$ & $\begin{array}{l}11.3 \\
1.03\end{array}$ & $\begin{array}{l}12.0 \\
1.04\end{array}$ & $\begin{array}{l}0.08 \\
0.15\end{array}$ & $\begin{array}{l}0.70 \\
0.06\end{array}$ \\
\hline & 2007 & $\begin{array}{l}\text { Milk } \\
\text { Milksolids }\end{array}$ & $\begin{array}{l}11.0 \\
0.99\end{array}$ & $\begin{array}{l}11.7 \\
1.09\end{array}$ & $\begin{array}{l}\mathrm{NA}^{1} \\
\mathrm{NA}\end{array}$ & $\begin{array}{c}0.05 \\
0.006\end{array}$ & $\begin{array}{l}0.39 \\
0.03\end{array}$ \\
\hline
\end{tabular}

${ }^{1}$ IRG not included in study during autumn 2007

soluble carbohydrates and lower levels of structural carbohydrate compared with typical perennials (Castle $\&$ Watson 1971). The other example of a grass with elevated WSC was a so-called high sugar ryegrass (HSG), selected in the UK to contain higher concentrations of soluble sugars. In this study the 'high' WSC grasses had higher concentrations of WSC than the standard control by margins ranging from 20 (spring 2005 ) to $41 \mathrm{~g} \mathrm{WSC} / \mathrm{kg} \mathrm{DM}$ (spring 2004), but there were no significant differences in autumn. There are few other data to directly compare these differences against, because of differences between studies in the seasonal timing of measurements and differences in the cultivars of grass used. Season of the year affects both the absolute concentrations of WSC and the differences between cultivars, and expression of the 'high sugar' trait cannot be assumed to occur under all conditions (i.e. a genotype x environment interaction; see Parsons et al. 2004; Halling et al. 2005). In an earlier field evaluation in NZ where we compared an HSG against a UK standard as the control to minimise differences other than WSC (including country of origin), the differences in WSC (10-20 g/kg DM) were considered too small to conduct animal-based evaluation. For this reason a NZ standard perennial ryegrass was chosen for this work to ensure differences were in the range seen as necessary for observing an animal response (e.g. $40 \mathrm{~g} / \mathrm{kg}$ DM cited by J.M. Moorby, pers. comm.), and also to reflect the choice facing the NZ 
farmer. Thus, the differences in WSC concentration reported here may reflect an inherent difference between UK and NZ lines (regardless of any selection for specific traits) plus expression of the high WSC trait. The increases of up to $41 \mathrm{~g} / \mathrm{kg}$ DM recorded here compare with increases of $39 \mathrm{~g} / \mathrm{kg}$ DM measured in the UK in mid summer (Miller et al. 2001b; comparing an HSG against a UK control), up to $32 \mathrm{~g} / \mathrm{kg}$ DM measured in The Netherlands (e.g. Taweel et al. 2006), and an average $25 \mathrm{~g} / \mathrm{kg}$ DM reported from eight European sites comparing an HSG with a UK control (Halling et al. 2005).

Obtaining a milk production response to higher WSC in ryegrass is by no means certain. An increase in milk production of $2.7 \mathrm{~kg}$ milk/cow/day $(+21 \%)$ was reported for cows fed indoors during late-lactation (Miller et al. 2001b) when the difference in WSC between the high (HSG) and low (control) WSC grasses was $39 \mathrm{~g} \mathrm{WSC} /$ $\mathrm{kg} \mathrm{DM}$, but not in early- or mid-lactation when the differences were between 40 and $82 \mathrm{~g} \mathrm{WSC} / \mathrm{kg}$ DM (Miller et al. 2000, 2001a; Moorby et al. 2006). Some caution is required in extrapolating from these studies because differences between grasses in WSC were manipulated. In one case this was achieved by cutting the 'high' WSC ryegrass at 2:00 PM and the 'low' at 10:00 AM using diurnal variation to amplify differences in WSC (Moorby et al. 2006). In the other case an additional $50 \mathrm{~kg} \mathrm{~N}$ fertiliser was applied to the control grass to depress its concentration of WSC relative to the less-fertilised high-WSC grass (Miller et al. 2000, 2001a). The increase in milk production in late-lactation recorded by Miller et al. (2001b) was attributed to higher digestible DM intake (DDMI), even though a similar increase in DDMI by cows in early-lactation did not translate to higher milk production. In a similar series of studies conducted in The Netherlands using cows indoors and at pasture, variations among ryegrass cultivars in grass WSC concentration of 24-32 g/ $\mathrm{kg}$ DM did not affect milk production or milk composition (Tas et al. 2005, 2006; Taweel et al. 2005, 2006).

In the UK studies (Miller et al. 2000, 2001a, b; Moorby et al. 2006), the protein concentration of the grass, ranging from $92-145 \mathrm{~g} \mathrm{CP} / \mathrm{kg} \mathrm{DM}$, was low in comparison to the concentration recorded in the studies reported here $(196-283 \mathrm{~g} / \mathrm{kg} \mathrm{DM})$, and in relation to typical concentrations for grazed pasture in NZ (e.g. mean 185 $\mathrm{g} \mathrm{CP} / \mathrm{kg}$ DM, range $50-362 \mathrm{~g} / \mathrm{kg}$ DM in 334 samples surveyed by Corson et al. 1999). One of the mechanisms of action proposed for elevated WSC is that it improves protein $(\mathrm{N})$ utilisation (Kingston-Smith \& Theodorou 2000), and this improved nitrogen retention gives rise to the animal benefits. Where a higher concentration of WSC has been offset by lower protein, Miller et al. (2000, 2001a) have argued that even maintaining the same level of milk production on a low protein (deficient for milk production) feed is substantive evidence of benefits from higher WSC (and from HSGs). However, grazed pasture in NZ seldom reaches such low concentrations of protein (Corson et al. 1999), and generally exceeds the protein requirements for milk production (NRC 2001). Where the cow's protein requirements are satisfied, benefits from higher WSC are more likely to be seen in reduced N excretion and consequently in environmental benefits. Pacheco et al. (2007), using multiple regression analysis of nitrogen partitioning data from these experiments, demonstrated that the efficiency of nitrogen utilisation for milk production was improved by additional WSC when the protein:WSC ratio in the forage was less than 1.3 (as it was in spring), but not when it was greater than 1.3 (as it was in autumn).

The reasons for the responses in milksolids production in autumn 2007 but not at other times are not clear. Responses in autumn may be influenced by the physiology of cows in late-lactation when there is greater partitioning of nutrients to body reserves and foetal growth compared with cows in early lactation. Furthermore, the composition of the grasses differed between spring and autumn. The overall mean concentration of WSC in autumn $(160 \mathrm{~g} / \mathrm{kg} \mathrm{DM})$ was lower than in spring $(200 \mathrm{~g} / \mathrm{kg} \mathrm{DM})$, but the concentrations of protein were higher (261 and $225 \mathrm{~g} / \mathrm{kg}$ $\mathrm{DM}$, for autumn and spring, respectively). At these lower concentrations of WSC and higher concentrations of protein in autumn, it is possible that cows may benefit more from smaller increments in WSC than they do in spring. A similar effect was shown by Carruthers and Neil (1997), where additional WSC increased milk production when the protein concentration of the grass was $18 \%$, but not when it was $13 \%$.

For these studies we selected one NZ perennial as the standard (control). This cultivar was selected on the basis that it is the NZ perennial that is most similar to the UK HSG perennial in other attributes such as flowering date, leaf size, tiller density, so that the comparison was based as much as possible on differences in one attribute, WSC. Both grasses were sown at the same time and managed in a similar way in terms of grazing frequency and fertiliser applications. Each grass was also endophytefree. In translating these results to practice, farmers, merchants and consultants should be aware that responses observed on farm to high WSC grasses will be influenced by the resident grass they are being compared against. For example, differences in the age of pastures, endophyte infection levels and the proportion of clover will all influence the observed responses, and these differences may have a larger influence on milk production than that attributable to WSC.

The pastures used for the studies reported here were sown without clover, and maintained with fertiliser $\mathrm{N}$. 
This approach was taken so that the effects of increased WSC on digestion and metabolism could be determined in the absence of the confounding effects that clover would introduce for protein $(\mathrm{N})$ intake and for the rate of dietary protein degradation in the rumen. Ultimately however, the value of grasses with elevated WSC should be assessed in the presence of clover because these grasses will be used on-farm in mixtures with clover.

\section{Conclusion}

These results indicate there may be a benefit to milk production in autumn associated with grasses that are nominally higher in WSC. However, this benefit cannot be attributed to elevated WSC per se, but it may be linked with associated changes in the composition e.g. less fibre, changes in protein:energy ratio, or possibly with physiological changes in cows as lactation advances.

\section{ACKNOWLEDGEMENTS}

This project is funded by Dairy InSight for the benefit of NZ dairy farmers. The contribution from Fred Potter for statistical advice, Lex Foote for maintaining experimental pastures and Kim Dowson for coordination of field work is gratefully acknowledged. We appreciate the enthusiastic support of the staff of Agricultural Services and the No 4 Dairy Unit, Massey University, in allowing access to farm facilities and services, and the numerous students and short-term staff who have assisted. Seed for the experimental pastures was contributed by NZ Agriseeds Ltd, and Germinal NZ Ltd.

\section{REFERENCES}

Carruthers, V.R.; Neil, P.G. 1997. Milk production and ruminal metabolites from cows offered two pasture diets supplemented with non-structural carbohydrate. New Zealand Journal of Agricultural Research 40: 513-521.

Castle, M.E.; Watson, J.N. 1971. A comparison between diploid and tetraploid ryegrass for milk production. Journal of Agricultural Science, Cambridge 77: 69-76.

Corson, D.C.; Waghorn G.C.; Ulyatt, M.J.; Lee, J. 1999. NIRS: Forage analysis and livestock feeding. Proceedings of the New Zealand Grassland Association 61: 127-132.

Cosgrove, G.P.; Burke, J.L.; Death, A.F.; Lane, G.A.; Fraser, K.; Pacheco, D. 2006. The effect of cloverrich diets on cows in mid lactation: production, behaviour and nutrient use. Proceedings of the New Zealand Grassland Association 68: 267-273.

Cosgrove, G.P.; Pacheco, D; Burke, J.L.; Death, A.F.;
Hickey, M.J.; Lane, G.A. 2007. Effects of water soluble carbohydrate in forage on aspects of nitrogen partitioning in cows. pp 350-358. In: Meeting the challenges for pasture-based dairying. Proceedings of the 3rd Dairy Science Symposium. Eds. Chapman, D.F.; Clark, D.A.; Macmillan, K.L.; Nation, D.P. 1820 September 2007, University of Melbourne, Victoria, Australia. Published by the National Dairy Alliance.

Edwards, G.R.; Parsons, A.J.; Rasmussen, S. 2007. High sugar grasses for dairy systems. pp 307-334. In: Meeting the challenges for pasture-based dairying. Proceedings of the 3rd Dairy Science Symposium. Eds. Chapman, D.F.; Clark, D.A.; Macmillan, K.L.; Nation, D.P. 18-20 September 2007, University of Melbourne, Victoria, Australia. Published by the National Dairy Alliance.

Halling, M.A.; Longland, A.C.; Martens, S.; Nesheim, L.; O'Kiely, P. 2005. Water soluble carbohydrate content of two cultivars of perennial ryegrass at eight European sites. p 131. In: Proceedings of the XX International Grasslands Congress, Dublin, Ireland. Eds. O’Mara, F.P. Wilkins, R.J. 't Mannetje, L.; Lovett, D.K.; Rogers, P.A.M.; Boland, T.M. Wageningen Academic Publishers.

Kingston-Smith, A.H.; Theodorou, M.K. 2000. Postingestion metabolism of fresh forage. New Phytologist 148: 37-55.

Lee, M.R.F.; Jones, E.L.; Moorby, J.M.; Humphreys, M.O; Theodorou, M.K.; MacRae, J.C.; Scollan, N.D. 2001. Production response from lambs grazed on Lolium perenne selected for an elevated water soluble carbohydrate concentration. Animal Research 50: 441-449.

Miller, L.A.; Baker, D.H.; Theodorou, M.K.; MacRae, J.C.; Humphreys, M.O.; Scollan, N.D.; Moorby, J.M. 2001a. Efficiency of nitrogen use in dairy cows grazing ryegrass with different water soluble carbohydrate concentrations. pp 377-378. In: Proceedings XIX International Grasslands Congress. Sao Paulo, Brazil. Eds. Gomide, J.A.; Mattos, W.R.M.; da Silva, S.C.

Miller, L.A.; Moorby, J.M.; Davies, D.R.; Humphreys, M.O., Scollan, N.D.; MacRae, J.C. Theodorou, M.K. $2001 \mathrm{~b}$. Increased concentration of water-soluble carbohydrate in perennial ryegrass (Lolium perenne L.): milk production from late-lactation dairy cows. Grass and Forage Science 56: 383-394.

Miller, L.A.; Theodorou, M.K.; MacRae, J.C.; Evans, R.T.; Humphreys, M.O.; Scollan, N.D.; Moorby, J.M. 2000. Efficiency of nitrogen use by dairy cows offered perennial ryegrass with high water soluble carbohydrate concentrations. pp 37-38. In: Proceedings of the 6th British Grasslands Society 
Research Conference. Aberdeen, September 2000.

Moorby, J.M.; Evans, R.T.; Scollan, N.D.; MacRae, J.C.; Theodorou, M.K. 2006. Increased concentration of water-soluble carbohydrate in perennial ryegrass (Lolium perenne L.). Evaluation in dairy cows in early lactation. Grass and Forage Science 61: 52-59.

Nocek, J.E.; Russell, J.B. 1988. Protein and energy as an integrated system. Relationship of ruminal protein and carbohydrate availability to microbial synthesis and milk protein. Journal of Dairy Science 70: 20702107.

NRC. 2001. Nutrient requirements of dairy cattle. 7th revised edition. National Academy of Sciences, Washington D.C.

Orr, R.J.; Rutter, S.M.; Penning, P.D.; Rook, A.J. 2001. Matching grass supply to grazing patterns for dairy cows. Grass and Forage Science 56: 352-361.

Pacheco, D.; Burke, J.L.; Cosgrove, G.P. 2007. An empirical model to estimate efficiency of nitrogen utilisation from cows grazing fresh forages. pp 409416. In: Meeting the challenges for pasture-based dairying. Proceedings of the 3rd Dairy Science Symposium. Eds. Chapman, D.F.; Clark, D.A.; Macmillan, K.L.; Nation, D.P. 18-20 September 2007, University of Melbourne, Victoria, Australia. Published by the National Dairy Alliance.

Parsons, A.J.; Rasmusen, S.; Xue, H.; Newman, J.A.; Anderson, C.B.; Cosgrove, G.P. 2004. Some 'high sugar grasses' don't like it hot. Proceedings of the New Zealand Grassland Association 66: 265-271.

Rook, A.J.; Huckle, C.A. 1995. Synchronisation of ingestive behaviour by grazing dairy cows. Animal Science 60: 25-30.

Tas, B.M.; Taweel, H.Z.; Smit, H.J.; Elgersma, A.; Dijkstra, J.; Tamminga, S. 2005. Effects of perennial ryegrass cultivars on intake, digestibility, and milk yield in dairy cows. Journal of Dairy Science 88: 3240-3248.

Tas, B.M.; Taweel, H.Z.; Smit, H.J.; Elgersma, A.; Dijkstra, J.; Tamminga, S. 2006. Effects of perennial ryegrass cultivars on milk yield and nitrogen utilisation in grazing dairy cows. Journal of Dairy Science 89: 3494-3500.

Tavendale, M.H.; Pacheco, D.; Lane, G.A.; Fraser, K.; Death, A.F.; Burke, J.L.; Hickey, M.J.; Cosgrove, G.P. 2006. The effects of ryegrass varieties differing in soluble sugar content on the rumen fermentation of amino acids and consequences for milk flavour chemistry. Proceedings of the New Zealand Grassland Association 68: 255-260.

Taweel, H.Z.; Tas, B.M.; Smit, H.J.; Elgersma, A.; Dijkstra, J.; Tamminga, S. 2005. Effects of feeding perennial ryegrass with an elevated concentration of water soluble carbohydrates on intake, rumen function and performance of dairy cows. Animal Feed Science and Technology 121:243-256.

Taweel, H.Z.; Tas, B.M.; Smit, H.J.; Elgersma, A.; Dijkstra, J.; Tamminga, S. 2006. Grazing behaviour, intake, rumen function and milk production of dairy cows offered Lolium perenne containing different levels of water-soluble carbohydrates. Livestock Science 102: 33-41. 